\title{
Sistem Pengelolaan Air Pada Settling Pond Untuk Tambang Terbuka
}

\section{${ }^{1}$ Noor Fauzi Isniarno, ${ }^{2}$ Muhammad Ilham Naufal, ${ }^{3}$ Iswandaru, ${ }^{4}$ Dono Guntoro, ${ }^{5}$ Wahyu Budi khorniawan}

\author{
1,2,3,4,5 Program Studi teknik Pertambanga, Fakultas Teknik, Universitas Islam Bandung \\ 'Noor_fauzi_isniarno@yahoo.com/noorfauzi@unisba.ac.id
}

\begin{abstract}
The importance of the need for water causes water to become a major factor in the sustainability of existing mining activities. In addition, the occurrence of silt deposition in the main pond is a separate problem which is very likely to cause silting of the main pond. This study aims to examine problems related to water and materials entering the mine. Based on the results of research using the calculation of the Gumbel distribution, through the Mononobe equation and rational formulas so that the runoff discharge is obtained where the total discharge that enters the washing pond is 710.81 m3/day. Thus, in order for the washing pond to optimally meet water needs, additional water is needed, which is $5,414.88 \mathrm{~m} 3 /$ day. To prevent silting of the main pond, periodic maintenance is needed, in this case the dredging of sedimentary material deposited in the pond. Based on the results of the study, it was found that $51,788 \mathrm{~kg}$ of solids were deposited in the pond carried by circulating water. With a reference of $60 \%$ of the pond capacity, the optimum time for dredging is once every 18 days.

Keywords: Mononobe, Gumbel distribution, rational formula, runoff discharge,
\end{abstract} Hydrology

\begin{abstract}
Abstrak. Pentingnya kebutuhan akan air menyebabkan air menjadi faktor utama dalam keberlangsungan kegiatan penambangan yang ada. Di samping itu, terjadinya pengendapan lumpur pada kolam utama menjadi permasalahan tersendiri yang sangat memungkinkan menyebabkan pendangkalan kolam utama. Penelitian ini bertujuan untuk meneliti permasalahan terkait air dan material yang masuk ke dalam tambang. Berdasarkan pada hasil penelitian yang menggunakan perhitungan distribusi Gumbel, melalui persamaan Mononobe serta rumus rasional sehingga didapatkan debit limpasan dengan total debit yang masuk ke dalam kolam pencucian sebesar 710,81 m3/hari. Dengan demikian, agar kolam pencucian dapat memenuhi kebutuhan air secara optimal, diperlukan air tambahan, yaitu sebesar 5.414,88 m3/hari. Untuk dapat mencegah pendangkalan kolam utama dibutuhkan perawatan berkala yang dalam hal ini adalah pengerukan material sedimen yang terendapkan di dalam kolam. Berdasarkan hasil kajian didapatkan sebanyak $51.788 \mathrm{~kg}$ padatan terendapkan di dalam kolam yang terbawa oleh air sirkulasi. Dengan acuan 60\% kapasitas kolam, waktu optimum untuk dilakukan pengerukan adalah setiap 18 hari sekali.

Kata Kunci: Mononobe, Distribusi Gumbel, rumus rasional, debit limpasan, Hidrologi
\end{abstract}

\section{Pendahuluan}

Perubahan global yang cepat (pertumbuhan penduduk, urbanisasi, dan kondisi cuaca ekstrim yang sering terjadi) secara kumulatif memengaruhi badan air setempat dan mengakibatkan perubahan hidrologi, ekologi, dan lingkungan yang tidak menguntungkan di sistem sungai utama (Kumar, 2020). Wawasan untuk hidrologi, suatu kualitas air dan perubahananya, diperlukan suatu monitoring mengenai siklus hidrologi (Sin, 2020). Perubahan penggunaan lahan 
dan tutupan lahan sangat penting untuk studi hidrologi karena memengaruhi limpasan permukaan, hasil sedimen, dan beban nutrisi dari daerah aliran sungai (Risal, 2020). Keberadaan air tanah sangat dipengaruhi oleh keberadaan zona resapan (Isniarno, 2020). hidrologi air permukaan dan hidrolika dalam beberapa dekade terakhir, terutama karena keunggulan kinerja yang luas dan kemudahan penggunaan (Kermani, 2020).

Penambangan terbuka adalah rekayasa sistem yang rumit yang memiliki banyak faktor tidak aman, seperti jumlah pekerja yang besar, tempat kerja yang tersebar, kondisi alam yang buruk, dan lingkungan kerja yang rumit, termasuk siklus hidrologi yang terjadi (Kaihuan, 2012). Air yang diakibatkan oleh area tambang terbuka bisa berdampak positif atau bisa berdampak negatif (Acharya, 2020). Air yang dibuang dari lokasi tambang terbengkalai dan/atau direklamasi dengan tingkat keasaman yang relatif lebih tinggi dan terus menjadi perhatian global karena berbagai dampak terhadap kualitas air permukaan dan air tanah (Acharya, 2020). Oleh karena itu, perlu dilakukan pengevaluasi kontribusi sumber-sumber dari keterdapatan air yang sangat diperlukan dalam pengelolaan air dalam sebuah operasi penambangan (scheiber, 2018).

Dalam sistem penambangan terbuka, masalah terpenting dalam kegiatan produksi penambangan adalah pengelolaan air permukaan. Pengelolaan air permukaan merupakan pengelolaan air secara terpadu, kegiatan pengelolaan dengan tujuan meminimalkan pengaruh negatif air permukaan yang terdiri dari metode drainase tambang, drainase tambang, pemisahan sedimen, dan pengendalian (Isniarno, 2020). Dalam metode untuk hidrogeoligi bawah permukaan, penulis dapat menggunakan metode geofisika, yaitu vertical electrical sounding (Isniarno, 2020). Efisiensi dalam perusahaan pertambangan bergantung kepada beberapa sektor di antaranya adalah sektor teknis, seperti hidrologi dan hidrogeologi (Isniarno, 2021).

Pengelolaan lanskap pada lahan tambang tidak terlepas dari tindakan konservasi air. Umumnya, komoditas pasir yang terdiri atas topsoil, lempung, pasir lempungan, dan pasir merupakan bagian dari lapisan batuan yang mampu melewatkan serta menyimpan air. Mempertimbangkan kondisi tersebut, pengolahan bahan galian dilakukan sebagai bentuk peningkatan nilai jual dari material yang menjadi salah satu konsen penting dalam dunia pertambangan, yakni ketersedian air yang harus selalu terpenuhi demi keberlangsungan kegiatan pencucian dan keberadaan material pengotor berupa lempung menjadi permasalahan penting dalam kegiatan pencucian pasir. Berdasarkan pemikiran tersebut, perlu dilakukannya pengkajian terhadap sistem pengelolaan air guna memenuhi kebutuhan pencucian pasir dan pengelolaan pengotor hasil pencucian yang didasarkan pada data hasil lapangan secara nyata yang kemudian diharapkan dapat diterapkan pada skala perusahaan.

\section{Metode Ilmiah}

Sistem penyaliran tambang (mine water management) adalah suatu sistem dalam pengelolaan air tambang yang meliputi aspek identifikasi dan kuantifikasi sumber air tambang, optimasi manajemen air tambang, perencanaan dan perancangan sarana prasarana, penyaliran, serta pengendalian dampak lingkungan akibat dari air tambang. Pada tambang terbuka, sumber air dapat berasal dari air limpasan hujan yang jatuh secara langsung pada area tambang, air luapan dari sumber air permukaan yang berada di sekitar lokasi tambang, seperti danau, sungai, rawa, dan air tanah apabila bukaan tambang memotong akuifer, sedangkan di tambang bawah tanah, umumnya air berasal dari lapisan 
akuifer yang terpotong akibat penggalian lubang bukaan serta dapat berasal dari kegiatan pendukung penambangan, seperti pekerjaan pengisian ruang bekas tambang (backfilling) oleh material tailing dalam bentuk lumpur (slurry).

Beberapa faktor yang menjadi perhatian dan harus dipertimbangkan dalam pembuatan rancangan sistem penyaliran pada tambang terbuka sebagai berikut:

\section{Curah Hujan}

Dalam daur hidrologi, presipitasi merupakan salah satu komponen utama yang merupakan proses jatuhnya air atmosferik ke permukaan bumi dalam bentuk hujan, salju, butiran es, dan sejenisnya. Di Indonesia yang merupakan daerah tropis, bentuk presipitasi yang dominan berupa hujan. Jika air di atmosfer yang dalam bentuk kumpulan butiran air berbentuk awan hasil dari proses kondensasi uap air setelah proses evaporasi mendingin, butiran air menjadi cukup besar yang kemudian jatuh ke permukaan bumi. Pengolahan data dalam analisis frekuensi curah hujan dilakukan guna memperoleh data curah hujan yang siap pakai untuk suatu perencanaan sistem penyaliran tambang. Hasil sebaran data dari perhitungan dispersi selanjutnya dapat digunakan untuk analisis curah hujan rencana. Data yang telah dihitung dapat direncanakan berdasarkan tingkat variansi data sehingga dalam penentuan curah hujan rencana akan memiliki tingkat keyakinan yang tinggi. Analisis curah hujan dapat dilakukan dengan beberapa persamaan, seperti distribusi normal, distribusi log normal, distribusi C.J Gumbel, dan distribusi Log-Person Tipe III.

\section{Intensitas Hujan}

Intensitas curah hujan merupakan jumlah curah hujan per satuan waktu yang relatif singkat dan dinyatakan dalam satuan $\mathrm{mm} / \mathrm{jam}$ yang artinya dalam waktu satu jam adalah sekian milimeter. Pada banyak kasus di tambang terbuka di Indonesia hanya tersedia data hujan harian yang diukur menggunakan alat penakar hujan biasa. Sementara itu, kejadian hujan yang harus ditangani oleh sistem penyaliran umumnya ditentukan oleh intensitasnya. Oleh sebab itu, dalam perancangan sarana penyaliran tambang, parameter besaran hujan yang biasanya digunakan adalah intensitas hujan. Rumus mononobe, dapat dipakai guna mengestimasi curah hujan jangka pendek dari data hujan 24 jam.

\section{Daerah Tangkapan Hujan (Catchment Area)}

Daerah tangkapan hujan merupakan luas permukaan yang jika terjadi hujan, air hujan akan mengalir ke daerah yang lebih rendah menuju ke titik pengaliran. Air yang jatuh kepermukaan bumi sebagian akan meresap ke dalam tanah, sebagian tercegat oleh tumbuhan (vegetasi), dan sebagiannya lagi bisa saja langsung jatuh di laut, sungai, danau, dan sebagainya. Semua air yang mengalir di permukaan bumi belum tentu dapat menjadi sumber air dari suatu sistem penyaliran yang kondisi tersebut tergantung pada daerah tangkapan hujan dan dipengaruhi oleh beberapa faktor di antaranya kondisi topografi, rapat tidaknya vegetasi, dan lain-lain. Daerah tangkapan hujan yang merupakan daerah air limpasan mengalir menuju ke sistem penyaliran alami pada suatu lokasi tertentu yang dalam penentuan luasannya berdasarkan peta topografi.

\section{Air Limpasan}

Air hujan yang tidak mengalami evaporasi dan infiltrasi akan menjadi limpasan. Untuk pembahasan mengenai limpasan, yang menjadi rujukan adalah daerah tangkapan hujan (watershed, catchment area). Areal tambang dapat digolongkan sebagai daerah tangkapan hujan kecil yang karakteristiknya adalah debit limpasan sangat dipengaruhi oleh karakteristik hujan atau dalam proses 
rancangan, frekuensi debit limpasan dapat didekati dari frekuensi hujan.

\section{Hasil dan Pembahasan}

Secara umum, daerah penelitian dikhususkan pada area sekitar kolam pencucian yang setiap hari secara kontinu terus dilakukan pemompaan. Kolam pencucian pasir berada pada lokasi yang sama dengan lokasi dumping material dari tambang sehingga memerlukan perhatian khusus yang dalam hal ini adalah ketersediaan air guna keberlangsungan proses pencucian material.

Pengambilan data secara langsung di lapangan meliputi data-data yang berhubungan erat dengan pengujian serta percobaan secara aktual di lapangan untuk mendapatkan perbandingan secara teoritis. Pengambilan data secara langsung meliputi sampel batuan, pengujianinfiltrasi, pengukuranhambatan pemompaan, hingga pengukuran dimensi aktual di lapangan, seperti ukuran pipa yang digunakan.

Pengambilan data tidak langsung pada kegiatan kerja praktik ini berasal dari hasil pengamatan laporan terdahulu dan kajian-kajian yang telah dilakukan sebelumnya, seperti pengumpulan data curah hujan, pengambilan data topografi lokal, hingga spesifikasi alat pemompaan. Diadakannya pengambilan data tidak langsung diharapkan dapat digunakan sebagai pendukung dalam mencapai tujuan yang ingin dituju serta digunakan sebagai pembanding, baik secara teoritis maupun aktual di lapangan.

Dalam melakukan penentuan luasan catchment area, hal itu didasarkan pada kecenderungan arah gerak aliran air yang berupa wilayah tangkapan yang polanya disesuaikan dengan kondisi topografi. Dengan adanya penentuan batas catchment area diharapkan setiap debit hujan akan terkonsentrasi sesuai batasan catchment area tersendiri. Dalam penentuan batas catchment area digunakan peta topografi, tetapi ada baiknya menggunakan peta rencana penambangan dan peta situasi tambang karena dinilai dapat mewakili kondisi aktual sesuai tahapan rencana tahunan. Berdasarkan pada pembuatan catchment area yang mengacu pada peta topografi rencana penambangan, tidak dijumpai daerah tangkapan hujan di luar lubang bukaan yang ada. Hal ini disebabkan kondisi topografi sekitar yang curam dengan arah aliran yang berlawanan punggungan dengan mengarah keluar area tambang. Luasan daerah catchment area dapat dilihat pada Tabel 1 .

Tabel 1. Catchment Area Daerah Penelitian

\begin{tabular}{lcc}
\hline Lokasi & Catchment Area (A) $\mathbf{~ m}^{2}$ & Persentase (\%) \\
\hline CA1 & $8.734,76$ & $9 \%$ \\
\hline CA2 & $49.090,25$ & $52 \%$ \\
\hline CA3 & $22.727,46$ & $24 \%$ \\
\hline CA4 & $13.512,91$ & $14 \%$ \\
\hline
\end{tabular}

Koefisien limpasan dapat ditentukan dengan mengetahui kondisi morfologi dan tata guna lahan daerah yang ingin ditentukan nilainya. Berdasarkan pada pengamatan kondisi lapangan serta diperkuat dengan melakukan penentuan persen lereng didapatkan bahwa kondisi kemiringan lereng daerah penelitian berada pada besaran persentase dengan nilai ratarata sebesar $>15 \%$. Apabila merujuk pada peta tutupan lahan dari kementerian kehutanan tahun 2017, daerah penelitian berada pada tutupan lahan pertanian lahan kering yang bercampur semak dan juga merupakan bagian lahan terbuka tambang. Dilanjutkan dengan nilai koefisien limpasan yang merupakan perbandingan kuantitas air limpasan terhadap curah hujan sebagai contoh pada CA 1, lalu didapatkan nilai koefisien limpasan sebesar 0.9 yang dapat diartikan bahwa air yang melimpas pada daerah tersebut sebesar $90 \%$, sedangkan sisanya akan meresap. Berikut merupakan nilai untuk masing-masing parameter yang dimaksudkan sesuai Tabel 2.

Untuk melakukan analisis data curah hujan dapat dilakukan pemahaman 
Tabel 2. Koefisien Limpasan Untuk Masing-Masing Catchment Area

\begin{tabular}{ccccc}
\hline Lokasi & Luas (A) $\mathbf{~ m}^{\mathbf{2}}$ & Kemiringan (\%) & $\begin{array}{c}\text { Pengelompokan Tata Guna } \\
\text { Lahan }\end{array}$ & Koefisien Limpasan \\
\hline CA1 & $8.734,76$ & $2-17 \%$ & Lahan Terbuka Tambang & 0,9 \\
\hline CA2 & $49.090,25$ & $2-17 \%$ & Lahan Terbuka Tambang & 0,9 \\
\hline CA3 & $22.727,46$ & $2-17 \%$ & Lahan Terbuka Tambang & 0,9 \\
\hline CA4 & $13.512,91$ & $2-17 \%$ & Lahan Terbuka Tambang & 0,9 \\
\hline
\end{tabular}

Tabel 3. Curah Hujan Bulanan Periode 2011 - 2020

\begin{tabular}{|c|c|c|c|c|c|c|c|c|c|c|c|c|c|}
\hline \multirow{2}{*}{ Tahun } & \multicolumn{12}{|c|}{ Curah Hujan (mm/hari) } & \multirow{2}{*}{ MAX } \\
\hline & Jan & Feb & Mar & Apr & Mei & Jun & Jul & Aug & Sep & Oct & Nov & Dec & \\
\hline 2011 & 5,17 & 7,30 & 9,46 & 12,11 & 5,95 & 7,77 & 2,64 & 2,17 & 4,72 & 5,94 & 10,00 & 8,98 & 12,1 \\
\hline 2012 & 7,72 & 7,83 & 8,54 & 7,42 & 4,26 & 4,46 & 4,10 & 5,90 & 2,45 & 4,26 & 9,18 & 13,13 & 13,1 \\
\hline 2013 & 17,53 & 10,25 & 9,40 & 8,23 & 7,53 & 8,05 & 7,86 & 3,32 & 2,55 & 4,12 & 5,89 & 14,03 & 17,5 \\
\hline 2014 & 19,62 & 12,83 & 9,45 & 10,23 & 6,33 & 7,36 & 5,81 & 3,59 & 3,81 & 3,38 & 9,39 & 12,39 & 19,6 \\
\hline 2015 & 12,72 & 17,75 & 11,90 & 8,59 & 6,16 & 2,91 & 3,35 & 2,43 & 3,23 & 3,18 & 9,62 & 10,25 & 17,8 \\
\hline 2016 & 11,56 & 15,13 & 13,11 & 12,00 & 6,94 & 6,48 & 7,44 & 5,37 & 10,98 & 11,92 & 11,82 & 6,61 & 15,1 \\
\hline 2017 & 10,16 & 15,22 & 10,66 & 10,05 & 8,03 & 4,59 & 3,17 & 2,61 & 6,76 & 12,02 & 14,41 & 9,53 & 15,2 \\
\hline 2018 & 6,84 & 16,86 & 12,04 & 8,61 & 4,44 & 6,69 & 1,34 & 3,94 & 4,92 & 7,54 & 10,76 & 11,17 & 16,9 \\
\hline 2019 & 12,80 & 14,83 & 8,93 & 12,25 & 7,33 & 3,19 & 2,48 & 1,76 & 1,68 & 4,91 & 6,62 & 12,56 & 14,8 \\
\hline 2020 & 12,27 & 20,39 & 19,58 & 10,40 & 10,78 & 4,59 & 4,81 & 4,19 & 6,95 & 11,94 & 9,84 & 9,99 & 20,4 \\
\hline
\end{tabular}

mengenai distribusi sebaran data intensitas curah hujan yang terjadi. Dengan mengetahui curah hujan rencana dapat diketahui intensitas curah dalam suatu periode ulang tahunan tertentu.

Berdasarkan pada curah hujan setiap bulan hujan, penentuan curah hujan rencana dengan menggunakan metode E. J Gumbel akan menunjukkan nilai keterjadian, baik sebelum maupun sesudah tahun yang dituju. Dengan menggunakan data curah bulanan sepuluh tahun ke belakang, untuk dapat mengetahui curah hujan harian perlu dibagi hari hujan yang terjadi pada bulan tersebut. Berikut merupakan data curah hujan bulanan periode 2011 - 2020 terdapat pada Tabel 3.

Intensitas curah hujan dapat diartikan sebagai besarnya jumlah hujan yang turun dalam satuan waktu sehingga perlu diketahui waktu konsentrasi yang dibutuhkan air untuk dapat mencapai titik terendah dari titik tertinggi pada suatu daerah tangkapan. Dengan diketahuinya besaran nilai untuk waktu konsentrasi (Tc), besarnya intensitas hujan dapat diketahui dengan menggunakan persamaan Mononobe. Berdasarkan hasil perhitungan yang telah dilakukan, dapat diketahui besaran intensitas curah hujan terhadap satuan waktu sebagaimana pada Tabel 4.

Bilamana seluruh parameter penentuan debit air limpasan telah tersedia, maka untuk menentukan besarnya nilai debit air limpasan dapat menggunakan persamaan rumus rasional

Tabel 4. Intensitas Curah Hujan

\begin{tabular}{cccccc}
\hline \multirow{2}{*}{ CAx } & \multicolumn{3}{c}{ Durasi } & \multicolumn{3}{c}{ Intensitas Hujan $(\mathbf{m m} / \mathbf{j a m})$} \\
\cline { 2 - 6 } & Menit & Jam & $\mathbf{t}=\mathbf{2}$ Tahun & $\mathbf{t}=\mathbf{5}$ Tahun & $\mathbf{t}=\mathbf{1 0}$ Tahun \\
\hline CA1 & 3,93 & 0,07 & 16,21 & 24,60 & 30,15 \\
\hline CA2 & 1,27 & 0,02 & 34,43 & 52,24 & 64,04 \\
\hline CA3 & 0,71 & 0,01 & 50,89 & 77,23 & 94,67 \\
\hline CA4 & 1,09 & 0,02 & 38,12 & 57,86 & 70,92 \\
\hline
\end{tabular}


Tabel 5. Debit Air Limpasan setiap Catchment Area

\begin{tabular}{ccccc}
\hline Lokasi & $\begin{array}{c}\text { Koefisien Limpasan } \\
(\mathbf{C})\end{array}$ & $\begin{array}{c}\text { Intensitas CH (I) } \mathbf{m} / \\
\text { detik }\end{array}$ & $\begin{array}{c}\text { Catchment Area } \\
(\mathbf{A}) \mathbf{~ m}^{\mathbf{2}}\end{array}$ & Debit (Q1) $\mathbf{~ m}^{\mathbf{3}} / \mathbf{d e t i k}$ \\
\hline CA1 & 0,9 & $6,8331, \mathrm{E}-06$ & $8.734,7692$ & 0,0537 \\
\hline CA2 & 0,9 & $1,4512, \mathrm{E}-05$ & $49.090,2531$ & 0,6412 \\
\hline CA3 & 0,9 & $2,1453, \mathrm{E}-05$ & $22.727,4628$ & 0,4388 \\
\hline CA4 & 0,9 & $1,6071, \mathrm{E}-05$ & $13.512,9123$ & 0,1955 \\
\hline
\end{tabular}

yang ditujukan untuk menentukan debit air limpasan pada daerah dengan kondisi permukaan relatif homogen. Yang terdapat pada Tabel 5.

Konduktivitas hidrolik merupakan suatu kondisi yang muncul sebagai akibat adanya ruang kosong pada pori material yang kemudian terisi oleh fluida terhadap waktu. Di lapangan, penentuan konduktivitas hidrologi dilakukan dengan menggunakan silinder yang terisi oleh air sehingga dapat diamati perubahan kondisi terhadap waktu (single ring). Dalam menentukan besaran nilai untuk gradien hidrolik air tanah dapat dilakukan menggunakan penampang air tanah lokasi yang dicari berdasarkan perbandingan antara jarak akuifer dengan panjang lintasan aliran akuifer atau secara matematis.

Berdasarkan

estimasi kesetimbangan kolam terlihat bahwa terjadinya kekurangan akan kebutuhan air guna pencucian material sebesar 5164,96 $\mathrm{m}^{3}$. Untuk mengatasi permasalahan yang dialami sebagai akibat tidak terpenuhinya volume kolam pencucian secara alami, maka untuk menjaga agar kolam pencucian tidak mengalami kekeringan, hal itu dapat menggunakan pilihan pengaliran air dari kolam utama dengan debit sama dengan lebih dari debit yang dikeluarkan oleh pompa dalam satuan jam.

Kemudian, dilakukannya perawatan terhadap kolam pengendapan (settling pond) sangat diperlukan demi menghindari terjadi pendangkalan dasar kolam. Upaya perawatan perlu dilakukan secara berkala mengingat kegiatan berlangsung secara kontinu yang dilakukan dengan melakukan pengerukan material sedimen dasar kolam pengendapan.

Berdasarkan pengamatan kondisi di lapangan dan peta geologi lokasi penelitian diketahui partikel yang terbawa oleh aliran air berupa partikel lempung-lanau yang memiliki ukuran butir menurut skala Wentworth sebesar $0,0625 \mathrm{~mm}$.

Berdasarkan data tersebut, debit air yang tersirkulasi masuk ke dalam kolam adalah sebesar 229,70 $\mathrm{m}^{3} / \mathrm{jam}$ yang dapat dilakukan perhitungan massa dan volume dari padatan serta air pada kolam utama. Karena padatan yang masuk ke dalam kolam kurang dari 40\% (11,58\%), digunakan Hukum Stokes untuk menghitung kecepatan pengendapan material. Adapun jenis material yang ikut teralirkan menuju kolam utama memiliki nilai densitas ( $\rho s)$ sebesar 1.946,92 Kg/m ${ }^{3}$ dan densitas air $(\rho)$ sebesar $996,14 \mathrm{Kg} / \mathrm{m}^{3}$ pada suhu $28,4^{\circ} \mathrm{C}$ dengan viskositas $(\mu)$ sebesar $0,000827 \mathrm{~m}^{2} / \mathrm{s}$ dan gravitasi sebesar 9,81 $\mathrm{m} / \mathrm{s}^{2}$. Menurut Virginia Soil and Water Conservation Commision (1980) dalam Simons (1982) merekomendasikan pengerukan dilaksanakan bilamana kuantitas sedimen berada pada nilai lebih kurang $60 \%$ dari total volume kolam untuk menjaga kondisi tetap optimum yang didapatkan waktu pengerukan kolam setiap 18 hari sekali.

\section{Kesimpulan dan Saran}

Kesimpulan yang dapat diambil dari penelitian ini adalah debit air yang dibutuhkan untuk memenuhi kebutuhan kolam pencucian pasir harian yang didapatkan berdasarkan 
pertimbangan bagian total debit yang dikeluarkan adalah sebesar 5.414,88 $\mathrm{m}^{3} /$ hari. Estimasi kuantitas material sedimen yang terendapkan dalam kolam utama adalah sebanyak $51.788 \mathrm{~kg} / \mathrm{jam}$ dengan kecepatan pengendapan sebesar $0,00245 \mathrm{~m} / \mathrm{s}$ yang ikut terbawa oleh debit aliran sirkulasi sebesar $229,70 \mathrm{~m}^{3} /$ jam. Dengan kuantitas material sedimen yang terendapkan sebesar $51.788 \mathrm{~kg} /$ jam, perawatan kolam yang dalam hal ini adalah waktu pengerukan, dapat dilakukan secara berkala setiap 18 hari sekali.

Saran dari penelitian ini adalah kolam pencucian dapat dilapisi dengan lapisan tahan air, seperti geomembrane, geotextile, geosynthetic, geogrid, geonet, geofoam, geocell, ataupun geocomposite karena kolam pencucian sendiri terdiri atas material yang mudah tererosi dan meloloskan air. Dengan menggunakan lapisan tahan air ini, diharapkan air tidak merembes dan mencegah kuantitas air dalam kolam berkurang. Pada beberapa bekas front kerja yang telah tidak terpakai didapatkan rembesan air tanah yang cukup deras pada kedalaman tertentu. Dilakukannya kajian terhadap rembesan air tersebut dapat menjadi suatu preferensi identifikasi permasalahan yang dapat muncul kemudian hari karena besar kemungkinan dapat memengaruhi kesetimbangan air sekitar.

\section{DAFTAR PUSTAKA}

Acharya, B. S. (2020). Acid mine drainage from coal mining in the United States - An overview. Journal of Hydrology, 125061.

Isniarno, N. F. (2020). Analysis of velocity groundwater in unconfines aquifer zone using infiltration measurement. IOP Conference Series: Materials Science and Engineering, 042047.

Isniarno, N. F. (2020). Hydrological monitoring in open PIT mining areas using geodatabase attribute in
Geographic Information Systems (GIS). IOP Conference Series: Materials Science and Engineering, 042043.

Isniarno, N. F. (2020). Optimasi Iterasi dan Root Means Square (RMS) Dalam Penentuan Batas Litologi dari Vertical Electrical Sounding (VES). Ethos : Journal Penelitian dan Pengabdian kepada masyarakat (sains \& Teknologi), 5058.

Isniarno, N.F.(2021). Analisis Discounted Cash Flow (DCF) Dalam Investasi tambang dan Kelayakan Ekonomi Pada Ekstraksi Timah dengan Menggunakan Teknologi Klorinasi Basah. Ethos : jurnal Penelitian dan Pengabdian Kepada Masyarakat, 6626.

Kaihuan, z. (2012). Research on Intrinsic Safety Method for Open-pit Mining. Procedia Engineering, 453-458.

Kermani, M. Z. (2020). Neurocomputing in surface water hydrology and hydraulics: a review of two decades retrospective, current status and future prospects. Journal of Hidrology, 125085.

Kumar, P. (2020). Socio-hydrology: A key approach for adaptation to water scarcity and achieving human well-being in large riverine islands. Progress in Disaster Science, Volume 8, December 2020, 100134.

Risal, A. (2020). Sensitivity of hydrology and water quality to variation in land use and land cover data. Agricultural Water Management, 106366.

Scheiber, 1. (2018). Quantification of properties of different water sources in a mining operation. Science of the Total Environment, 587-599.

Sin, Y. (2020). Changes in hydrology, water quality, and algal blooms in a freshwater system impounded with engineered structures in a 
100 | Isniarno, et al.

temperate monsoon river estuary. Journal of Hydrology: Regional Studies, 100744. 